\title{
Fluctuation of academic performance of medical students selected by affirmative action policies (PIMESP)
}

\section{Flutuação do desempenho acadêmico de alunos de medicina selecionados por políticas afirmativas (PIMESP)}

\author{
Atílio Marcomini Neto' (D) $\mid$ atiliocsp@gmail.com \\ Patrícia da Silva Fucuta' (1) patriciafucuta@gmail.com \\ Vânia Maria Sabadotto Brienze' (D) vania.brienze@hospitaldebase.com.br \\ Alba Regina de Abreu Lima' (D) alba.lima09@gmail.com \\ Sérgio Luís Aparecido Brienze' (D) sergio.brienze@famerp.br \\ Júlio César André1 (1) julio.andre@famerp.br
}

\begin{abstract}
Introduction: Almost 20 years since the beginning of affirmative action implementation, there is still much discussion about the real effectiveness of these measures, especially regarding academic performance, comparing "quota holders" to "non-quota holders", with doubts arising about whether the former can keep up with the latter.

Objective: To establish a profile and compare the academic performance and other aspects related to the academic life of "quota holder" students (Inclusion Program with Merit in Public Higher Education in São Paulo - PIMESP) with the other students in their respective classes selected via broad competition (BC).

Method: Retrospective cohort of $1^{\text {st }}$ to $3^{\text {rd }}$-year medical students, divided in BC or PIMESP. The following were assessed: arithmetic mean of the final grades of the curricular subjects; final approval status (FAS) in the subjects; frequency; books borrowed from the library (BBLi) and participation in monitoring/academic center. Continuous variables were compared by Student's t-test or Mann-Whitney test and categorical by chi-square or Fisher's exact test. Values $p<0.05$ were considered significant.

Results: Of the 237 students included in the sample, all had completed the $1^{\text {st }}$ year (2015, 2016 and 2017 entrants), 158 students (2015 and 2016 entrants) the $1^{\text {st }}$ and $2^{\text {nd }}$ years, and $78(32.9 \%)$ had completed the $3^{\text {rd }}$ year (2015 entrants) at the time of the survey. In the analysis of all those who had completed the $1^{\text {st }}$ year, where $16 \%$ were PIMESP, there was a difference in mean final grades and FAS, higher for BC students and no difference for attendance, BBLi, participation in monitoring and academic center. In the analysis of those who had completed the $2^{\text {nd }}$ year, where $15.8 \%$ were PIMESP, there was no difference between any of the studied variables. The analysis of those who had completed the $3^{\text {rd }}$ year, where $15.4 \%$ were PIMESP, once again showed difference between the averages of final grades and FAS, higher for BC students, but with a less marked difference, and there were no significant differences for the other variables.

Conclusion: We observed a fluctuation of academic performance among PIMESP students, towards inferior outcomes, when compared to BC students, throughout the first three years of medical school, but not for other variables. No increase in the dropout rate was observed, contrary to what is found in the literature.
\end{abstract}

Keywords: Medical Education; Affirmative Actions; Medical Students; Academic Performance.

\section{RESUMO}

Introdução: Depois de quase 20 anos desde o início da materialização das ações afirmativas, ainda há muita discussão sobre a real efetividade dessas medidas, principalmente, no que tange ao desempenho acadêmico, quando se comparam "cotistas" e "não cotistas", surgindo dúvidas se aqueles conseguem acompanhar estes.

Objetivo: Este estudo teve como objetivos traçar um perfil do desempenho acadêmico e compará-lo e os demais aspectos relacionados à vida acadêmica dos alunos "cotistas" (Programa de Inclusão com Mérito no Ensino Superior Público Paulista - Pimesp) com os demais alunos de suas respectivas turmas selecionados via ampla concorrência (AC).

Método: Trata-se de coorte retrospectiva de alunos da primeira à terceira série de Medicina, divididos em AC ou Pimesp. Avaliaram-se os seguintes aspectos: média aritmética das notas finais das disciplinas curriculares, situação final de aprovação nas disciplinas (SFA), frequência, títulos emprestados na biblioteca (TEB) e participação em monitorias/centro acadêmico. As variáveis contínuas foram comparadas pelo teste t de Student ou Mann-Whitney, e as categóricas, por qui-quadrado ou exato de Fisher. Valores $p<0,05$ foram considerados significantes.

Resultado: Participaram do estudo 237 alunos. Todos haviam concluído a primeira série (ingressantes de 2015, 2016 e 2017); 158 alunos (ingressantes de 2015 e 2016), a primeira e segunda séries; e 78 (32,9\%) haviam concluído a terceira série (ingressantes de 2015) no momento da pesquisa. Na análise de todos os que haviam concluído a primeira série, dos quais 16\% faziam parte do Pimesp, houve diferença nas médias das notas finais e da SFA, maior para alunos $A C$, e não houve diferença para frequência, TEB, participação em monitorias e centro acadêmico. Na análise dos que haviam concluído a segunda série, dos quais 15,8\% faziam parte do Pimesp, não houve diferença entre nenhuma das variáveis estudadas. A análise dos que haviam concluído a terceira série, dos quais 15,4\% faziam parte do Pimesp, mostrou novamente diferença entre as médias das notas finais e da SFA, maior para alunos $A C$, porém com uma diferença menos acentuada, e não houve diferenças significativas para as demais variáveis.

Conclusão: Observou-se flutuação do desempenho acadêmico dos estudantes Pimesp, para menor, em relação aos estudantes AC, ao longo dos três primeiros anos do curso de Medicina, mas não para outras variáveis. Não foi observado aumento do índice de evasão, contrariando a literatura.

Palavras-chave: Educação Médica; Ações Afirmativas; Estudantes de Medicina; Desempenho Acadêmico.

${ }^{1}$ Faculdade de Medicina de São José do Rio Preto, São José do Rio Preto, São Paulo, Brazil. 


\section{INTRODUCTION}

Education is a fundamental activity in any society, and it is considered one of the factors of socioeconomic development. It is an important component for the sociocultural, political and economic development of society and the citizens ${ }^{1,2}$.

Great economic development has occurred during the last century, due in large part to science and education. Therefore, it was necessary to define education not only in terms of its effect on economic growth, but also on human development ${ }^{3}$, which reaffirms that higher education and schools are seen as the driving forces of economic development 2. This idea is disseminated as a solution to the problems of existing inequalities between countries and individuals ${ }^{2}$.

The recognition of racism and racial discrimination as structuring mechanisms of social inequalities in Brazil was admitted by the government as of the 1990s. Specific public policies were created to promote the rights of the black population 4 .

Among these inequalities, access to higher education stands out, where 60 to $65 \%$ of blacks are disadvantaged compared to whites in terms of higher education attendance rates, according to the 2010 Census ${ }^{4,5}$.

Throughout history, higher education in Brazil has been restricted to representatives of the economically higher classes, with few examples of individuals from the lower strata of society who managed to enter the academic world, progress and maintain themselves during the course of their choice, especially medical school ${ }^{6}$.

The creation and implementation of affirmative actions were then proposed, aiming to reverse this unequal picture and to promote inclusion and diversity. According to Gomes (2001):

[...] affirmative actions can be defined as a set of public and private policies of a compulsory, optional or voluntary nature, which were conceived aiming to fight racial, gender and national origin discrimination, as well as to correct the present effects of discrimination practiced in the past, with the objective of achieving the ideal of effective equality of access to fundamental goods such as education and employment (p.40) ${ }^{7,8}$.

These policies have a known origin in India in the 1940s and were known as "reservation policies" and not "affirmative actions". The first system of quotas was implemented for the benefit of lower castes in parliament for religious reasons and later ratified by the constitution of $1947^{2,8,9}$. Affirmative action policies in the US were created in the 1960s, in which the political and social mobilization known as the Civil Rights Movement played a decisive role. In July 1964, the US Congress passed the Civil Rights Act with anti-discrimination measures and it became a federal law. In higher education, both public and private institutions were compelled to adopt affirmative action programs. In the case of private institutions, they are, to a large extent, dependent on public money that reaches these institutions through scholarships and research funding. The objective of these actions was to promote diversity and the resulting educational benefits ${ }^{9}$. Although the Indian experience is the oldest, it was the North American experience that exerted the greatest influence in Brazil ${ }^{8,9}$.

In Brazil, it is difficult to establish what was the first historical experience with affirmative actions. Rosana Heringer (2001) ${ }^{10}$ considers the "Lei do Boi" (the "Ox's Law) as a pioneer. which in 1968 reserved university vacancies for farmers' children, while Sabrina Moehlecke (2002) ${ }^{11}$ believes that the legal framework for the affirmative action started with the 1988 Constitution, which already provided a reservation of civil servant jobs for people with physical and mental disabilities ${ }^{9}$.

Therefore, the adoption of affirmative actions took place after a process of redemocratization, where different racial groups and organizations started demanding rights in an organized and public manner ${ }^{8,9}$. Considering this scenario, after the country's redemocratization and the approval of the new national constitution, the debate on the subject and on the creation of policies to democratize access to higher education started, to be used as an instrument of racial transformation 12-14.

The march "Zumbi dos Palmares against Racism, for Citizenship and Life" took place in 1995, where its National Executive Committee presented to the Federal Government a document emphasizing the need to address the problem of racial discrimination in the national political agenda and to create and implement policies to promote equality. This document, among other recommendations, included the adoption of affirmative actions in higher education aimed at black candidates ${ }^{8}$.

In this scenario, in 1999 and 2000, two Bills of Law (PL, Projetos de Lei) that provided for the creation of affirmative actions were presented to the National Congress: PL n. 73 of 1999, which originated the Quota Law, and PL n. 3198 of 2000, which originated the Racial Equality Statute ${ }^{8}$. The debates about the adoption of affirmative actions in Brazil increased after the country participated in the "World Conference against Racism, Racial Discrimination, Xenophobia and Correlated Intolerance" held in Durban (South Africa) in 20014. This event can be considered a special moment during the process of affirmative policy implementation in Brazil, as support to access to the labor market and universities, targeting low-income public school students and also those self-declared black, brown and indigenous groups ${ }^{2}$.

The first Brazilian universities to adopt Affirmative Action Programs (PAAs, Programas de Ações Afirmativas) giving priority to social and/or racial criteria were Universidade do Estado do Rio 
de Janeiro (UERJ) and Universidade Estadual do Norte Fluminense Darcy Ribeiro (UENF) in 2000, followed by Universidade de Brasília (UnB) in $2003^{8,9}$. Universidade Estadual de Mato Grosso do Sul (UEMS) and Universidade Estadual da Bahia (UEB) were also pioneers. Although the first quota systems were aimed at black students, most state universities adopted social criteria, which favored students from public schools ${ }^{4}$.

As Law n. 12.711 / 2012 was related to the issue of affirmative actions in federal institutions, as of 2012, the Deans of São Paulo universities and the government of the state of São Paulo started the discussions regarding the creation of something similar to the Quota Law, aiming to regulate the affirmative actions in state educational institutions. In 2013, the Inclusion Program with Merit in Public Higher Education in São Paulo (PIMESP, Programa de Inclusão com Mérito no Ensino Superior Público Paulista) was created, in which each higher education institution is free to decide on how the actions should be applied and the proportion of vacancies destined to them ${ }^{15,16}$.

From 2002 onwards, the inclusion of quota holders in the university context exacerbated debates about the consequences of this policy and the impacts of its adoption. These debates resulted in studies that included approaches on the evaluative perception of the quotas of different students in the university context, their coexistence between different classes and ethnic groups, the debate around meritocracy and equality, the trajectory of undergraduate students, the bias of debating about affirmative actions and the difficulties of permanence at university ${ }^{17}$.

Almost 20 years after the advent of affirmative actions, there is still a lot of discussion about the real effectiveness of these measures, mainly, several questions have been raised about the performance comparing "quota holders" and "nonquota holders", raising doubts if the former can keep up with the latter, with studies concluding that "quota holders" perform well below non-quota holders. Other studies showed that both categories show equivalent performance, whereas others show a slight advantage for freshman students that entered university through affirmative actions ${ }^{14,18-20}$.

In the context of state policies, the Faculdade de Medicina de São José do Rio Preto (FAMERP) joined PIMESP in 2014, reserving $15 \%$ of the total number of vacancies in all its courses according to socioeconomic and racial criteria. For the medical course, it represents a total of 12 vacancies, 4 of which are reserved for self-declared black, brown or indigenous students and the rest for students who have attended full elementary and high school in public schools.

Thus, the present study aims to draw a profile of academic performance, and other aspects directly related to academic life, of students from the medical course at FAMERP, selected via PIMESP, and compare the academic performance and other aspects related to the academic life of PIMESP students with those of other students from their respective classes who entered university through broad competition.

\section{METHODS}

This was a retrospective cohort based on academic performance of freshman students selected by PIMESP (P) and by broad competition (BC), in the 2015/2017 triennium, developed in 2017 and 2018, after being approved by the Research Ethics Committee of Faculdade de Medicina de São José do Rio Preto (REC/FAMERP) under number 2.067.522, on May 17, 2017, where the waiver of the Free and Informed Consent Form (FICF) was requested and granted, as it comprises data collection from a database or similar, endorsed by Article IV of Resolution 466/12 of the National Health Council ${ }^{21}$.

\section{Sample}

The sample consisted of medical school students with a pass status, who were regularly enrolled and attending classes at FAMERP, since the year 2015 - the year in which the selection process started with PIMESP - up to the students with a pass status, who were regularly enrolled and taking the course in the year 2017, the year of the last college admittance exam prior to data collection, comprising a total of 237 participants. The sample was divided into 3 groups: 2017 freshmen, who had attended the first grade; 2016 freshmen, who had attended the first and second grades; and 2015 freshmen who had attended the first, second and third grades of the medical course. Each group was subdivided into 2 subgroups for analysis: students enrolled via PIMESP and students enrolled via broad competition (BC).

\section{Collected data}

The data were collected by the researchers using institutional records from the following data sources: FAMERP Management System (SGF - Sistema de Gestão FAMERP), locally developed integrated school management system; Scientific Library and Documentation Service (SBDC, Serviço de Biblioteca e Documentação Científica) Prof. Dr. José Victor Maniglia, through SOPHIA@2021 Prima library management software; Adjunct Board of Education (DAE, Diretoria Adjunta de Ensino), which holds the records of monitoring data at FAMERP; Adjunct Board of Extension (DAEx, Diretoria Adjunta de Extensão), which holds the records of data from academic leagues at FAMERP; Euryclides Zerbini Academic Center (CAEZ), academic center of the Medical School, and its respective Athletic Center, at FAMERP.

The following data were included: school performance, represented by the simple arithmetic mean $(M)$ of the final 
grades of the disciplines of the curricular structure of the school year; final status (FS: approval, approval with final assessment or post-school assessment or failure); frequency $(F)$; titles borrowed from the library; and participation in extracurricular activities (participation in tutoring, participation in noncollegiate bodies of student representation, such as academic and athletic centers, and in academic leagues).

\section{Data analysis}

Exploratory data analysis included mean, median, standard deviation and variation for continuous variables and number and proportion for categorical variables ${ }^{22}$. The normal or non-normal distribution of continuous variables was analyzed using asymmetry, kurtosis and the KolmogorovSmirnov test. The comparison of numerical variables between groups was performed using the Mann-Whitney test and the comparison of categorical variables between groups was performed using the Pearson's chi-square test ${ }^{22-24}$. Statistical analysis was performed using the IBM-SPSS Statistics version 24 software (IBM Corporation, NY, USA). All tests were two-tailed and $p$ values $<0.05$ were considered significant.

\section{RESULTS}

Of the 237 students included in the sample, all had completed the $1^{\text {st }}$ year (2015 and 2016 freshmen), 158 students (2015 and 2016 freshmen) had finished the $1^{\text {st }}$ and $2^{\text {nd }}$ years, and $78(32.9 \%)$ had finished the $3^{\text {rd }}$ year (2015 freshmen) of the medical course at the time of the research. The results were organized and will be described per attended year. It is noteworthy that for the studied period there were no changes in the curricular structure, schedules, or teachers who taught the disciplines of the curricular structure.

\section{Results related to the overall performance observed in the $1^{\text {st }}$ year of the medical course}

Of the 237 students who attended the 1st year (2015, 2016 and 2017 freshmen), 38 (16\%) entered the medical course through PIMESP. The characteristics of the overall performance of the 237 students are described in Table 1.

The comparative data on student performance can be seen in Table 2.

In the comparative analysis between the groups of freshmen who entered medical school through BC and PIMESP, a significant difference can be observed in the averages of the final grades of the disciplines of the curriculum structure of the $1^{\text {st }}$ year: $8.04 \pm 0.48$ and $7.67 \pm 1.06$ for $B C$ and PIMESP students, respectively ( $p=0.028$ ), as well as for the final result approval in the number of disciplines, higher for $B C$ students $(p=0.01)$. As for participation in extracurricular activities, there was a higher proportion of BC students in Academic Leagues in the $1^{\text {st }}$ year of medical school, when compared to PIMESP students $(p=0.012)$.

\section{Results related to the overall performance observed} in the $2^{\text {nd }}$ year of the medical course

A total of 158 students attended the 2 nd year of medical school (2015 and 2016 freshmen), of which 25 (15.8\%) had entered the course through PIMESP. As for the final status of the student, all students had a pass status in this year (Table 3).

At this stage of the course, there was no significant difference between the averages of the final grades: $8.73 \pm 0.36$ and $8.71 \pm 0.42$ for $B C$ and PIMESP students, respectively $(p=0.83)$, as well as in the students' final results, regarding the number of subjects. The only extracurricular activity that showed a significant difference between the groups was participation in Academic Leagues, 119 (91.5\%) and 16 (72.7\%) for BC and PIMESP students participating in leagues, respectively $(p=0.020)$.

\section{Results related to the overall performance observed} in the $3^{\text {rd }}$ year of medical school

A total of 78 students attended the 3rd year of medical school (2015 freshmen), of which 12 (15.4\%) had entered the course through PIMESP. As for the students' final results (number of disciplines), all students had a pass status in this year. Table 4 shows the overall characteristics of performance

Table 1. Overall performance of students observed in the $1^{\text {st }}$ year of undergraduate medical school (2015, 2016 and 2017 freshmen). (FAMERP, 2018).

\begin{tabular}{cc}
\hline Characteristic & $\mathbf{n}=\mathbf{2 3 7}$ \\
\hline $\begin{array}{c}\text { Grades }^{\mathrm{a}} \\
\text { Frequency, \% }\end{array}$ & $7.98 \pm 0.63$ \\
& $94.7(82.36-100)$ \\
\hline $\begin{array}{c}\text { Students' final results, number of disciplines } \\
\text { Students with a pass status }\end{array}$ & $11(2-19)$ \\
$\begin{array}{c}\text { Students with a pass status after the } \\
\text { final evaluation }\end{array}$ & $1(0-5)$ \\
$\begin{array}{c}\text { Students with a pass status after the } \\
\text { school term }\end{array}$ & $0(0-4)$ \\
Students who failed & $0(0-8)$ \\
\hline $\begin{array}{c}\text { Library book withdrawals } \\
\text { Participation in monitoring, } \mathrm{n}(\%)\end{array}$ & $48(0-172)$ \\
Participation in the Academic / Athletic \\
Center, $\mathrm{n}$ (\%)
\end{tabular}

Continuous variables are described as mean, standard deviation or median (range); categorical variables are described as number (percentage).

a Simple arithmetic mean of the final grades of all disciplines of the curriculum of the attended school year. 
Table 2. Comparative analysis of student performance observed in the $1^{\text {st }}$ year of medical school (2015, 2016 and 2017 freshmen). (FAMERP, 2018).

\begin{tabular}{|c|c|c|c|}
\hline Characteristic & $\begin{array}{l}\text { Entered through PIMESP } \\
\qquad \mathrm{n}=38\end{array}$ & $\begin{array}{l}\text { Entered through } \mathrm{BC} \\
\mathrm{n}=199\end{array}$ & p-value \\
\hline Grades $^{\mathrm{a}}$ & $7.67 \pm 1.06$ & $8.04 \pm 0.48$ & 0.028 \\
\hline Frequency, \% & $94.05(83.5-99.6)$ & $94.9(82.4-100)$ & 0.392 \\
\hline \multicolumn{4}{|l|}{ Students' final results, number of disciplines } \\
\hline Students with a pass status & $10(2-12)$ & $11(5-12)$ & 0.01 \\
\hline $\begin{array}{l}\text { Students with a pass status after the final } \\
\text { evaluation }\end{array}$ & $1(0-5)$ & $0(0-5)$ & 0.029 \\
\hline Students with a pass status after the school term & $0(0-2)$ & $0(0-4)$ & 0.039 \\
\hline Students who failed & $0(0-8)$ & $0(0-1)$ & 0.061 \\
\hline Library book withdrawals & $46(4-126)$ & $48(0-172)$ & 0.637 \\
\hline \multicolumn{4}{|l|}{ Participation in monitoring activities, $n$ (\%) } \\
\hline Yes & $8(33.3)$ & $41(31.3)$ & \multirow{2}{*}{0.844} \\
\hline No & $16(66.7)$ & $90(68.7)$ & \\
\hline \multicolumn{4}{|l|}{ Academic / Athletic Center, n (\%) } \\
\hline Yes & $4(10.5)$ & $29(14.7)$ & \multirow{2}{*}{0.496} \\
\hline No & $34(89.5)$ & $168(85.3)$ & \\
\hline \multicolumn{4}{|l|}{ Academic Leagues, $n$ (\%) } \\
\hline Yes & $25(67.6)$ & $167(84.8)$ & \multirow{2}{*}{0.012} \\
\hline No & $12(32.4)$ & $30(15.2)$ & \\
\hline
\end{tabular}

Continuous variables are described as mean, standard deviation or median (range); categorical variables are described as number (proportion).

a Simple arithmetic mean of the final grades of all disciplines of the curriculum of the attended school year.

PIMESP - Inclusion Program with Merit in Public Higher Education in São Paulo; BC - broad competition.

Table 3. Overall performance of students observed in the $2^{\text {nd }}$ year of medical school (2015 and 2016 freshmen). (FAMERP, 2018).

\begin{tabular}{cc}
\hline Characteristic & $\mathbf{n = 1 5 8}$ \\
\hline Grades $^{\mathrm{a}}$ & $8.73 \pm 0.37$ \\
Frequency, \% & $95.8(77.7-100)$ \\
\hline
\end{tabular}

Students' final results, number of disciplines

Students with a pass status $\quad 14(4-15)$

Students with a pass status after the final evaluation

$$
0(0-3)
$$

Students who failed

$$
0(0-4)
$$

Library book withdrawals

$23(0-143)$

Monitoring activities, $\mathrm{n}(\%)$

48/153 (31.4)

Academic / Athletic Center, n (\%)

Participation in Academic Leagues, n (\%) $\quad$ 135/152 (88.8)

Continuous variables are described as mean, standard deviation or median (range); categorical variables are described as number (percentage).

a Simple arithmetic mean of the final grades of all disciplines of the curriculum of the attended school year.
Table 4. Overall performance of students observed in the $3^{\text {rd }}$ grade of medical school (2015 freshmen). (FAMERP, 2018).

\begin{tabular}{cc}
\hline Characteristic & $\mathbf{n = 7 8}$ \\
\hline Grades $^{\mathrm{a}}$ & $8.27 \pm 0.42$ \\
Frequency, \% & $95.7(84.9-99.9)$ \\
\hline
\end{tabular}

Students' final results, number of disciplines

$$
\text { Students with a pass status }
$$$$
11(7-11)
$$

Students with a pass status after the final evaluation

$0(0-3)$

Students with a pass status after the school term

$0(0-1)$

Book withdrawals

$21(0-110)$

Monitoring activities, $\mathrm{n}(\%)$

$2 / 75(2.7)$

Academic / Athletic Center, n (\%)

20/75 (26.7)

Participation in Academic Leagues

$53 / 75(70.7)$

Continuous variables are described as mean, standard deviation or median (range); categorical variables are described in number (percentage).

a Simple arithmetic mean of the final grades of all disciplines of the curriculum of the attended school year. 
Table 5. Comparative analysis of the performance of students in the $3^{\text {rd }}$ year of medical school (2015 freshmen). (FAMERP, 2018).

\begin{tabular}{|c|c|c|c|}
\hline Characteristic & $\begin{array}{l}\text { Entered through PIMESP } \\
n=11\end{array}$ & $\begin{array}{l}\text { Entered through BC } \\
\qquad \mathrm{n}=64\end{array}$ & p-value \\
\hline Grades $^{\mathrm{a}}$ & $8.02 \pm 0.55$ & $8.32 \pm 0.38$ & 0.032 \\
\hline Frequency, \% & $94.7(84.9-99.5)$ & $95.8(85.6-99.9)$ & 0.327 \\
\hline \multicolumn{4}{|l|}{ Students' final results, number of disciplines } \\
\hline Students with a pass status & $11(7-11)$ & $11(9-11)$ & 0.022 \\
\hline Students with a pass status after the final evaluation & $0(0-3)$ & $0(0-2)$ & 0.022 \\
\hline Students with a pass status after the school term & $0(0-0)$ & $0(0-1)$ & 0.016 \\
\hline Book withdrawals & $23(2-57)$ & $21(0-110)$ & 0.544 \\
\hline \multicolumn{4}{|l|}{ Monitoring activities, $\mathrm{n}(\%)$} \\
\hline Yes & $0(0)$ & $2(3.1)$ & \multirow{2}{*}{1.00} \\
\hline No & $11(100)$ & $62(96.9)$ & \\
\hline \multicolumn{4}{|l|}{ Academic / Athletic Center, $n$ (\%) } \\
\hline Yes & $3(27.3)$ & $17(26.6)$ & \multirow{2}{*}{1.00} \\
\hline No & $8(72.7)$ & $47(73.4)$ & \\
\hline \multicolumn{4}{|l|}{ Participation in Academic Leagues, $n$ (\%) } \\
\hline Yes & $7(63.6)$ & 46 (71.9) & \multirow{2}{*}{0.721} \\
\hline No & $4(36.4)$ & $18(28.1)$ & \\
\hline
\end{tabular}

Continuous variables are described as mean, standard deviation or median (range); categorical variables are described as number (proportion).

a Simple arithmetic mean of the final grades of all disciplines of the curriculum of the attended school year.

PIMESP - Inclusion Program with Merit in Public Higher Education in São Paulo; BC - broad competition.

and participation in extracurricular activities of the assessed students.

Comparative data on student performance at this stage are depicted in Table 5.

At this stage of the course, there was, again, a significant difference between the averages of the final grades of the curriculum disciplines: $8.02 \pm 0.55$ and $8.32 \pm 0.38$ for PIMESP and BC students, respectively $(p=0.032)$. Additionally, the students' final results, regarding the number of disciplines with a pass status was higher for $B C$ students $(p=0.02)$. There was no significant difference regarding class attendance, book withdrawals, as well as participation in extracurricular activities.

\section{DISCUSSION}

Although it is clear that the adoption of public policies of inclusion has brought major changes to the profile of the medical student in institutions that have implemented such policies, as well as their effectiveness in democratizing the access to medical school, with greater demographic, social, economic and ethnic pluralism ${ }^{25}$, there seems to be no consensus, most likely due to the scarcity of research in this area, regarding the performance, permanence in the course and perspectives regarding the professional future of these students when compared to those who enter the course through broad competition, that is, the actual impacts of affirmative action policies of inclusion on the performance of the medical professional.

The selection methods used by medical schools must reliably identify whether candidates are likely to be successful in medical training and, ultimately, to become competent physicians. However, there is little consensus on methods that reliably assess non-academic attributes, and longitudinal studies assessing predictors of success after qualification are insufficient ${ }^{26}$.

National and international studies show similar or even superior final performance of students admitted to higher education through affirmative action policies and even through legal measures ${ }^{27}$, based almost exclusively on academic performance and attributes ${ }^{27,28}$. Even so, as a rule, they conclude by emphasizing the need for consistent programs to ensure the permanence and completion of the course, concentrating on pedagogical strategies and curriculum design (of academic nature) and on the social and psycho-emotional support to minimize possible impacts of adaptation to the new reality ${ }^{29}$.

Academic performance, usually also called school performance ${ }^{30}$, is based on one or more classroom assessments in a given period, with varied formats and determined by characteristics that are inherent to the teacher (more or less demanding). However, in the assessed institution, all students 
have the same disciplines, taught by the same teachers, which allows the comparison between school years of the same course.

Therefore, the report of a pioneering experience at an Italian university, where the group of interest and the control group had the same year of admission, identical classes, programs, teachers and classrooms, making the comparison of the two groups highly valid and improving the reliability of the data ${ }^{27}$, it must be taken into account that it was a group of interest comprising students who did not pass the admission test and not admission resulting from an affirmative action. This is not the case here, where the group of interest includes students who have passed the admission test, although grounded on an affirmative action policy that guaranteed competition between students who had similar educational opportunities up to the time they applied for admission to the university. Nevertheless, our sample, although from different school years, had the same classes, programs, teachers and identical classrooms, which does not make the comparison of the groups less valid. Furthermore, other important studies in this area were carried out along the same lines of research ${ }^{28}$.

Throughout the study period, school performance, observed from the average grades of students admitted through $\mathrm{BC}$, remained higher when compared to students admitted through PIMESP. This is observed, above all, in the $1^{\text {st }}$ year of undergraduate school, where the difference between grades is the highest among the three analyzed years. However, at the end of the second year, the difference practically ceased to exist, making the average of the two groups practically the same. However, at the end of the $3^{\text {rd }}$ year, we observed the reappearance of a difference; however, lower than that observed at the end of the first year.

This seems to be the most often explored aspect, albeit little, in the comparison between students who entered medical school through BC and inclusion public policies, and no other references were found, specifically involving PIMESP, which explores this issue.

Some authors are categorical about this fact. Pena et al. (2020), analyzing medical students from Universidade Federal de Ouro Preto (UFOP), who entered medical school in 2013, state that "academic performance after entering the university is equivalent between quota holders and students admitted through broad competition" ${ }^{\prime 31}$.

Although the students' doings showed no problems, as there were no failures during the study period, contrary to the findings of Rocha \& Júnior (2020) that low academic performance at the beginning of the course is a predictor of academic failure ${ }^{32}$, the item "final results" showed a significant difference at the beginning of the course, as it happened with the grades, with $B C$ students showing better final performance than PIMESP students, proportionally, with more direct pass statuses. In this item, the behavior observed with the grade averages was once again repeated, with differences no longer being significant at the end of the second year and reappearing at the end of the third year.

Another analyzed parameter that showed significance was the item "academic leagues". At the end of the first year, we see that $82.1 \%$ of all students had participated in leagues, with BC students participating more than PIMESP students $(84.8 \%$ of the former against $67.6 \%$ of the latter; difference of $17.2 \%$ ). For the second year, the total number of students who attended the leagues increased (88.8\%) and the difference between the categories continued to be significant, with BC students participating in greater numbers $(91.5 \%$ against $72.7 \%$; difference of $18.8 \%$ ), with the relative difference between them remaining practically constant. However, in the third year, the overall participation of students in leagues decreases, reaching $70.7 \%$ of the total, as well as the difference in the participation of groups $(71.9 \%$ for BC and $63.6 \%$ for PIMESP; $8.3 \%)$, without significance between the values, demonstrating an approximation factor between the groups.

It must be borne in mind that attending academic leagues requires time, which can be precious for the quota student not only to minimize any shortcomings of lower quality elementary and high school education than their peers had, but also to try to balance the problems resulting from socioeconomic conditions, as the literature shows that quota students, regardless of the modality, for the most part do not receive financial help from the family ${ }^{33}$.

They face unique challenges as they integrate into a primarily middle-to-upper-class environment in the school of medicine, and schools must be sensitive to the students' needs, both helping to acculturate them and reconsidering how cultural competence curricula address socioeconomic disparities. ${ }^{34}$

When analyzing the results of the school years separately, the idea that $B C$ students perform better than those approved through PIMESP is reinforced ${ }^{17}$. When comparing the two first years, we observe that the differences shown by the two groups decrease, reinforcing the idea that the differences tend to disappear ${ }^{35}$. However, the information related to the third year shows a different scenario, with the reappearance of the disparity between the income groups, but with a less marked difference than that found at the beginning of undergraduate school.

Although studies, without differentiating the admittance method, demonstrate greater stress due to excessive pressure on students in the basic cycle when compared to the clinical $\mathrm{cycle}^{36}$, it must be considered that the cycle change, although developing to become more and more imperceptible, remains a source of stress, again raising the issue of facing a scenario of greater difficulty than previously seen. 
Another explanation for this fluctuation could be related to self-assessment and motivation. Self-assessment is a complex and challenging critical skill, where self-criticism can range from chronic degrading feelings, also referred to as the 'imposter syndrome', to inflated self-perception assessments ${ }^{37}$. Anxiety and significant doubts about one's capacity, particularly in the early years of the course, can further harm academic performance. Motivation, in turn, is a psychological process that activates behavior and directs it towards a goal. Thanks to motivation, students are capable of striving to persist in and achieve their goals. This concept includes, as very important variables related to personality, achievement expectations, causal attributions, self-efficacy, personal worth and, above all, self-esteem and self-concept, once again permeating the field of self-assessment ${ }^{38}$. Motivational beliefs influence the process of anticipating situations, whether based on self-efficacy beliefs, outcome expectations and intrinsic value beliefs ${ }^{39}$.

We also observed that the obtained data contradict the idea that quotas would contribute to worsening the quality of the course, in addition to increasing dropout rates due to the difficulty of quota students in keeping up with the performance of non-quota students ${ }^{17,40}$. The obtained information shows that the number of students per class remained practically constant, considering the maximum number of 80 students in each year, a finding corroborated by Pena et al. (2020), who shows that in the medical course at UFOP, there were no records of dropout among the quota holders ${ }^{31}$.

Moreira (2017) states that the trajectory between admission to the undergraduate course, performance throughout training and, subsequently, professional performance depends on a complex and individual combination of elements and that it includes conditions prior to undergraduate school (in which the socioeconomic condition factors have their place), conditions during undergraduate school (curriculum, pedagogical experiences, feelings of satisfaction and belonging to the group) and conditions after graduation (job market and family and personal conditions that define their choice of area for the future professional practice $)^{29}$.

Regarding conditions during undergraduate school, the challenge of keeping a student at the university is something that obviously imposes itself on all students, particularly on the most economically disadvantaged ones, especially in the case of courses that require students to invest in personal equipment, in addition to the issue of the completeness of the course, which practically requires exclusive dedication ${ }^{41}$.

Even though there is a lack of resources from the previous academic life, financial and cultural resources that explain the deficit of quota students (such as family income and the need for them to have paid employment, data not collected here) and that the existence of these differences can be seen from the perspective of white privilege in society, routinely labeled "meritocracy", this is questionable. Fostering this questioning as a universal abstract value, which justifies the existence of some common measure of humanity's aptitude and intelligence and assuming that meritocracy cannot have a definition excluded from people's social and material circumstances, the adoption of quotas has nothing to do with the exclusion of merit, but with the utilization of selection criteria that promote competition among students who have had similar educational opportunities up to the moment they apply to enter the university. Thus, students from public schools, black, brown and indigenous students who will be selected will represent a fraction of those who applied for a place at the university and will therefore be the best among them ${ }^{42,43}$.

However, studies that, despite showing lower academic performance for those benefiting from any type of bonus, do not show any differences in medical residency admission ${ }^{29}$ or no impact on subsequent clinical performance ${ }^{44}$, assume that socially disadvantaged students, after entering undergraduate school through some inclusive strategy, become indistinguishable from the others at the end of the course ${ }^{45}$.

Finally, our results lead us to believe that, throughout the course, students adapt to the new environment, get to know the rules of the school game better, learn the student trade and become university students, regardless of school selection method $^{31,46}$.

It is also noteworthy that there are other gains arising from greater diversity: bringing graduates closer to the profile of the population among which they will practice their profession, enables them to deal with diversity and take advantage of the wealth of experiences that such diversity can offer ${ }^{29}$.

By recruiting, admitting and supporting students from lower socioeconomic backgrounds, medical schools can gain a more diverse medical workforce and perhaps their graduates will be more likely to practice medicine at diverse communities, thus helping to address the health disparities of our continental country.

\section{CONCLUSIONS / FINAL CONSIDERATIONS}

The results obtained suggest that students approved via PIMESP have greater difficulty when faced with a scenario of greater complexity than previously seen. This is evidenced by differences, both at the beginning of the course and at the beginning of the more specific study for the medical field, when the clinical cycle starts.

Our data also contradict the idea of an increase in dropout rates due to the difficulty of quota students in keeping 
up with the performance of non-quota ones, since the number of students per class remained practically constant.

As for the other aspects directly related to academic life, such as books borrowed from the library and participation in extracurricular activities, there were no significant differences between PIMESP and BC students.

This behavior of the assessed parameters, of an approximation followed by the reappearance of a disparity, needs further investigation in the future, by analyzing a larger number of students and other years of medical school, in addition to including the numbers related to the fourth year of the medical course, which is theoretically more difficult and the one that demands the most from the students in the study institution, and comparing them to those collected in the previous years. Additionally, it is necessary to estimate whether these differences will affect the final training of the medical professional or if they will disappear in the final half of the course, not interfering with these students' future medical practice.

The time has come to end comparisons and call on institutions and their administrative and teaching staff to assume responsibilities aiming to guarantee the provision of equity conditions.

\section{AUTHORS' CONTRIBUTION}

Atílio Marcomini Neto and Patrícia da Silva Fucuta were responsible for data collection, analysis and interpretation and for the final writing of the results and statistical analysis. Vânia Maria Sabadotto Brienze and Júlio César André wrote the final version of the manuscript. Alba Regina de Abreu Lima and Sérgio Luís Aparecido Brienze carried out a critical review of the manuscript.

\section{CONFLICTS OF INTEREST}

The authors declare no conflicts of interest.

\section{SOURCES OF FUNDING}

The authors declare no sources of funding.

\section{REFERENCES}

1. Delors J. Educação: um tesouro a descobrir. Relatório para a Unesco da Comissão Internacional sobre Educação para o Século XXI. Paris, Porto: Unesco, ASA; 1996 [acesso em 20 ago 2021]. Disponível em: http://www. dominiopublico.gov.br/.

2. Fritznel A. Análise do Programa de Ação Afirmativa e Inclusão Social (PAAIS) implementado pela UNICAMP no período de 2005-2014 [dissertação]. Campinas: Universidade de Campinas; 2015 [acesso em 15 out 2021]

3. Frigotto G. Educação e crise do capitalismo real. 4a ed. São Paulo: Cortez; 2000. 41 p.

4. Aguiar MM, Piotto DC. Desigualdade à brasileira: capital étnico-racial no acesso ao ensino superior. Educação. 2018;41(3):478-491 [acesso em 9 ago 2021]
5. Corbucci PR. Evolução do acesso de jovens à educação superior no Brasil. Brasília: Ipea; 2014.

6. Chehuen Neto JA, Godinho ÍA, Barbosa RM, Barbosa GC, Ferreira RE. The medical school: opportunities offered and the affirmative action. Rev Méd Minas Gerais. 2014;24(2):188-195. doi: 10.5935/2238-3182.20140052

7. Gomes JBB. Ação afirmativa \& princípio constitucional da igualdade: o direito como instrumento de transformação social. A experiência dos EUA Rio de Janeiro: Renovar; 2001

8. Anhaia BC. A "lei de cotas" no ensino superior brasileiro: reflexões sobre a política pública e as universidades federais [tese]. Porto Alegre: Universidade Federal do Rio Grande do Sul; 2019 [acesso em 20 ago 2021]. Disponível em: https://www.lume.ufrgs.br/bitstream/ handle/10183/196058/001094918.pdf?sequence $=1$

9. Feres Júnior J, Campos LA, Daflon VT, Venturini AC. Ação afirmativa: conceito, história e debates. Rio de Janeiro: EdUERJ; 2018 [acesso em 15 set 2021]. Disponível em: http://books.scielo.org/id/2mvbb.

10. Heringer R. Mapeamento de ações e discursos de combate às desigualdades raciais no Brasil. Estud Afro-Asiáticos. 2001;23(2):1-43.

11. Moehlecke S. Ação afirmativa: história e debates no Brasil. Cad Pesqui. 2002;(117):197-217 [acesso em 10 jul 2021]. Disponível em: http://www.scielo.br/scielo.php?script=sci_arttext\&pid=S0100$15742002000300011 \&$ lng=pt\&tlng=pt.

12. dos Santos JHP, Santos IP. Da epistemologia à hermenêutica: compreendendo as ações afirmativas. Direito e Democr. 2013;14(2):82-95

13. Daflon VT, Feres Júnior J, Campos LA. Ações afirmativas raciais no ensino superior público brasileiro: um panorama analítico. Cad Pesqui. 2013;43(148):302-27 [acesso em 30 jul 2021]. Disponível em: from: http://www.scielo.br/scielo.php?script=sci_arttext\&pid=S0100$15742013000100015 \&$ lng $=$ pt\&tlng=pt.

14. de Souza JLS, Wust C, Kremer R, Pulga VL, Lousada VL. I Seminário políticas públicas e ações afirmativas Universidade Federal de Santa Maria Observatório de ações afirmativas. In: Políticas afirmativas e inclusão no curso de medicina da UFFPS/PF: rompendo paradigmas. Santa Maria: UFSM, Afirme, Observatório de ações afirmativas para acesso e permanência nas Universidades Públicas da América do Sul, 2015 [acesso em 15 mar 2021].

15. Minto LW. Ensino médio e ensino superior em São Paulo: notas críticas sobre o Pimesp. Educ em Rev. 2014;14(2):53-68.

16. Nogueira F. Cotas raciais no curso de medicina da UFRGS na perspectiva docente: rupturas e configurações tecidas na garantia do direito à educação superior pública [resumo]. Porto Alegre: Salão UFRGS 2016: III SALÃO EDUFRGS. Pontifícia Universidade Católica do Rio Grande do Sul; 2015 [acesso em 10 mai 2021]. Disponível em: https://lume.ufrgs. br/bitstream/handle/10183/156860/EDUFRGS2016_Resumo_51808. pdf? sequence $=1$ \&isAllowed $=y$.

17. Peixoto ALA, Ribeiro EMBA, Bastos AVB, Ramalho MCK. Cotas e desempenho acadêmico na Ufba: um estudo a partir dos coeficientes de rendimento. Avaliação Rev da Avaliação da Educ Super. 2016;21(2):569-92 [acesso em 30 jun 2021]. Disponível em: http://www.scielo.br/scielo.php?script=sci_ arttext\&pid=S1414-40772016000200569\&lng=pt\&tlng=pt.

18. Goldemberg J. Ações afirmativas nas universidades brasileiras. Jornal da USP 2016;2:4 [acesso em 18 abr 2020]. Disponível em: http://www. acadciencias.org.br.

19. De Assis YS. Relações sociais e sentidos de justiça social após a adoção da política de cotas na Universidade Federal de Sergipe. Rev TOMO 2014; 24 297-334 [acesso em 10 mai 2021]. Disponível em: https://seer.ufs.br/index. php/tomo/article/view/3193.

20. Velloso J. Cotistas e não-cotistas: rendimento de alunos da Universidade de Brasília. Cad Pesqui. 2009;39(137):621-44 [acesso em 12 mai 2020]. Disponível em: http://www.scielo.br/scielo.php?script=sci arttext\&pid=S0100-15742009000200014\&lng=pt\&tlng=pt.

21. Brasil. Resolução $n^{\circ} 466$, de 12 de dezembro de 2012. Aprova as seguintes diretrizes e normas regulamentadoras de pesquisas envolvendo seres humanos. Brasília; 2012.

22. Conover WJ. Practical nonparametric statistics. New York: John Wiley \& Sons; 1998. 
23. Siegel $S$, Castellan NJ. Estatística não paramétrica para ciências do comportamento. 2a ed. Porto Alegre: Artmed; 2006. 488 p.

24. Field A. Descobrindo a estatística usando o SPSS. 5a ed. Porto Alegre: Grupo A; 2020. 1104 p.

25. Silva MLAM, Amaral E, Machado HC, Passeri SMRR, Bragança JF. Influência de políticas de ação afirmativa no perfil sociodemográfico de estudantes de Medicina de universidade brasileira. Rev Bras Educ Med. 2018;42(3):36-48.

26. Patterson F, Knight A, Dowell J, Nicholson S, Cousans F, Cleland J. How effective are selection methods in medical education? A systematic review. Med Educ. 2016;50(1):36-60.

27. Migliaretti G,BozzaroS, Siliquini R, Stural, Costa G, Cavallo F. Is the admission test for a course in medicine a good predictor of academic performance? A case-control experience at the school of medicine of Turin. BMJ Open. 2017 Nov 1;7(11):e017417. doi: 10.1136/bmjopen-2017-017417.

28. Moreira GO, Passeri S, Velho PENF, Ferraresi F, Appenzeller S, Amaral E. The academic performance of scholarship students during medical school. Rev Bras Educ Med. 2019;43(3):163-9 [acesso em 30 abr 2021]. Disponível em: http://www.scielo.br/scielo.php?script=sci_ arttext\&pid=S0100-55022019000300163\&tlng=en.

29. Moreira GO. Validade preditiva do processo seletivo para admissão em medicina e o papel das ações afirmativas em relação ao desempenho durante a graduação e na seleção para a residência médica [tese]. Campinas: Universidade Estadual de Campinas; 2017 [acesso em 10 ago 2020]. Disponível em: http://repositorioslatinoamericanos.uchile.cl/ handle/2250/1368259

30. Baccaro TA, Shinyashiki GT. O desenvolvimento da orientação profissional no Brasil. Rev Bras Orientaç Prof. 2003;4(2):1-11.

31. Pena MAC, Matos DAS, Coutrim RME. Percurso de estudantes cotistas: ingresso, permanência e oportunidades no ensino superior. Avaliação Rev da Avaliação da Educ Super. 2020;25(1):27-51 [acesso em 30 jan 2021]. Disponível em: http://www.scielo.br/scielo.php?script=sci_ arttext\&pid=S1414-40772020000100027\&tlng=pt.

32. Rocha BASR, Toledo Júnior A. Predictive factors of graduation delay in a medical program: a retrospective cohort study in Brazil, 2010-2016. Rev Bras Educ Med. 2020;44(1), e001 [acesso em 28 out 2021]. Disponível em: http://www.scielo. $\mathrm{br} /$ scielo.php?script=sci_arttext\&pid=S0100-55022020000100201\&tlng=en.

33. Souza PGA, Pôrto ACCA, Souza A, Silva Júnior AG, Borges FT. Perfil socioeconômico e racial de estudantes de Medicina em uma universidade pública do Rio de Janeiro. Rev Bras Educ Med. 2020;44(3), e090 [acesso em 28 out 2021]. Disponível em: http://www.scielo.br/scielo.php?script=sci_ arttext\&pid=S0100-55022020000300211\&tlng=pt.

34. Girotti JA, Park YS, Tekian A. Ensuring a fair and equitable selection of students to serve society's health care needs. Med Educ. 2015;49(1):84-92. doi: $10.1111 /$ medu. 12506 .
35. Mendes Junior AAF. Uma análise da progressão dos alunos cotistas sob a primeira ação afirmativa brasileira no ensino superior: o caso da Universidade do Estado do Rio de Janeiro. Ens Avaliação e Políticas Públicas em Educ 2014;22(82):31-56 [acesso em 10 mai 2019]. Disponível em: http://www. scielo.br/scielo.php?script=sci_arttext\&pid=S0104-40362014000100003\&ln $\mathrm{g}=\mathrm{pt} \&$ tlng $=\mathrm{pt}$.

36. Loureiro EMF. Study of the relationship between stress and life style of Medical Students. Rev Bras Educ Med. 2008;32(2):273.

37. Villwock JA, Sobin LB, Koester LA, Harris TM. Impostor syndrome and burnout among American medical students: a pilot study. Int J Med Educ 2016 Oct 31;7:364-9 [acesso em 10 mai 2019]. Disponível em: http:// www.ijme.net/archive/7/impostor-syndrome-among-american-medicalstudents/.

38. Álvarez MMG. Estrategia metodológica para desarrollar el aprendizaje autorregulado em los estudiantes del primer ciclo de la carrera de administración em una universidad privada de Lima [tesis]. La Molina: Universidad San Ignacio de Loyola; 2020.

39. Salgado FAF, Polydoro SAJ, Rosário P. Programa de Promoção da Autorregulação da Aprendizagem de Ingressantes da Educação Superior Psico-USF. 2018;23(4):667-79 [acesso em 10 mai 2019]. Disponível em: http://www.scielo.br/scielo.php?script=sci_arttext\&pid=S1413 $82712018000400008 \&$ Ing $=$ pt\&tlng $=p t$

40. Reibnegger G, Caluba H-CC, Ithaler D, Manhal S, Neges HM, Smolle J. dropout rates in medical students at one school before and after the installation of admission tests in Austria. Acad Med. 2011 Aug;86(8):10408 [acesso em 20 mai 2019]. Disponível em: http://journals.lww. com/00001888-201108000-00029.

41. Lopes MA, Braga MLDS. Acesso e permanência da população negra no ensino superior. Brasília: UNESCO 2007. 358 p.

42. Alves Filho M. Brasil já teve políticas afirmativas para brancos europeus. Jornal da Unicamp. 2017 [acesso em 30 out 2021]. Disponível em: https:// vermelho.org.br/2017/06/14/brasil-ja-teve-politicas-afirmativas-parabrancos-europeus/.

43. Chalhoub S. A meritocracia é um mito que alimenta as desigualdades. Jornal da Unicamp. 2017 [acesso em 10 abr 2019]. Disponível em: http:// verborragio.blogspot.com/2017/06/a-meritocracia-e-um-mito-quealimenta.html.

44. Cooter R, Erdmann JB, Gonnella JS, Callahan CA, Hojat M, Xu G. Economic diversity in medical education. Eval Health Prof. 2004 Sep 24;27(3):252-64. doi: 10.1177/0163278704267041

45. Wiliam D. What counts as evidence of educational achievement? The role of constructs in the pursuit of equity in assessment. Rev Res Educ. 2010 Mar 1;34(1):254-84. Doi: 10.3102/0091732X09351544.

46. Coulon A. A condição de estudante: a entrada na vida universitária. Salvador: Edufba; 2008. 278 p. 